\title{
The Effect of Supplemental Glycine or Threonine on the Elevated Plasma Methionine Concentration and the Decreased Feed Intake of Chicks Fed the Methionine Excess Diet
}

\author{
Hiroshi Ueda*, Hiro-omi Yokota and Iwao TAsaki \\ Faculty of Agriculture, Nagoya University, Nagoya-shi 464.
}

HARPER et al." have proposed an aminostatic hypothesis whereby altered blood amino acid pattern, especially resulting from amino acid imbalance, may serve as a signal to a feed intake-regulatory mechanism. In amino acid excess, DANIEL and WAISMAN $^{2)}$ reported that plasma concentration of amino acid in excess in a diet was markedly elevated and that the extent of this elevation tended to correlate with the toxicity of amino acid. A marked elevation of plasma methionine is one of the most consistent biochemical changes that occur in rats $^{4)}$ and chicks ${ }^{51}$ fed the methionine excess diet.

Adverse effect caused by excess methionine is known to be alleviated by adding glycine $^{3,4,6)}$. BENEVENGA and HARPER ${ }^{4)}$ reported that the elevated plasma methionine concentration due to excess methionine was lowered by adding glycine and they further suggested that the lowered plasma methionine accelerated the feed intake, though feed intake data were not available. KATZ and BAKER $^{6)}$ showed that threonine was also effective in alleviating the methionine toxicity, but it is not clear whether or not supplemental threonine lowers the plasma methionine level.

The experiment reported below was designed to investigate the effect of supplemental glycine or threonine on the elevated plasma methionine concentration and the decreased feed intake of chicks fed the methionine excess diet.

\section{Experimental}

Day-old Single Comb White Leghorn male chicks were raised on a commercial chick starter diet for 7 days. On day 8, chicks were individually weighed and assigned on a weight basis to 12 replicates of 2 chicks each. Three replicates were randomly allotted into each experimental treatment. They were reared in metabolism cages in a room at $30^{\circ} \mathrm{C}$, and feed and water were supplied freely for 5 days from day 8 to day 13 .

The control diet contained $(\mathrm{g} / \mathrm{kg}$ diet); isolated soybean protein (crude protein $78.1 \%$ ) 128.0 , cornstarch 539.95 , glucose, 200.0, corn oil 40.0, cellulose 30.0 , mineral mixture $56.3^{7)}$, choline chloride 2.0 , L-methionine 2.5 and glycine 1.25 . Adequate

* Present address: University Farm, Faculty of Agriculture, Kagawa University, Kagawa-ken 769-23. 
amounts of vitamins $(0.75 \mathrm{~g} / \mathrm{kg})^{8)}$ were added to the control diet. The control diet contained only $10.0 \%$ crude protein but the proportion of amino acid composition was similar to that of the well-balanced diet ${ }^{9)}$. The methionine excess diet was formulated by adding $1.5 \%$ L-methionine to the control diet. Equimolar amounts of glycine $(0.75 \%)$ or L-threonine $(1.19 \%)$ were supplemented to the methionine excess diet. All amino acid supplements replaced equal amounts of cornstarch.

At the end of the experimental period, body weight and feed intake were measured and blood was taken by heart puncture from all chicks after continuous access to the feed. Blood plasma of each replicate was pooled and plasma concentrations of methionine, glycine and threonine were determined using a Hitachi KLC-5 amino acid analyzer by the same procedure described previously ${ }^{5}$.

\section{Results}

The effects of supplemental glycine or threonine on the performance of chicks fed the experimental diets and plasma concentrations of methionine, glycine and threonine are summarized in table 1.

Table 1. Effects of supplemental glycine or L-threonine to the methionine excess diet on body weight gain, feed intake, gain/feed ratio and plasma concentrations of methionine, glycine and threonine.

\begin{tabular}{lcccccc}
\hline & $\begin{array}{c}\text { Body } \\
\text { weight gain } \\
(\mathrm{g} / \mathrm{ch} \text {.ck })\end{array}$ & $\begin{array}{c}\text { Feed } \\
\text { intake } \\
(\mathrm{g} / \mathrm{chick})\end{array}$ & $\begin{array}{c}\text { Gain/feed } \\
(\mathrm{g} / 100 \mathrm{~g})\end{array}$ & $\begin{array}{c}\text { Plasma } \\
\text { methionine }\end{array}$ & $\begin{array}{c}\text { Plasma } \\
\text { glycine } \\
(\mu \text { moles } / 100 \mathrm{~m} l)\end{array}$ & $\begin{array}{c}\text { Plasma } \\
\text { threonine }\end{array}$ \\
\hline $\begin{array}{l}\text { Control } \\
\text { Methionine }\end{array}$ & $27.7 \pm 3.4^{\mathrm{a}}$ & $68.3 \pm 2.2^{\mathrm{a}}$ & $40.3 \pm 3.8^{\mathrm{a}}$ & $10.2 \pm 1.3^{\mathrm{a}}$ & $60.1 \pm 2.6^{\mathrm{a}}$ & $25.7 \pm 5.4^{\mathrm{a}}$ \\
$\begin{array}{l}\text { excess } \\
+ \text { Glycine }\end{array}$ & $5.0 \pm 0.6^{\mathrm{b}}$ & $37.3 \pm 3.2^{\mathrm{bc}}$ & $13.3 \pm 0.4^{\mathrm{b}}$ & $520.7 \pm 77.0^{\mathrm{b}}$ & $45.4 \pm 1.1^{\mathrm{b}}$ & $19.8 \pm 4.0^{\mathrm{a}}$ \\
+ Threonine & $8.0 \pm 0.6^{\mathrm{c}}$ & $38.0 \pm 1.5^{\mathrm{b}}$ & $21.0 \pm 0.8^{\mathrm{c}}$ & $272.6 \pm 38.8^{\mathrm{c}}$ & $227.3 \pm 33.8^{\mathrm{c}}$ & $57.0 \pm 7.2^{\mathrm{b}}$ \\
\hline
\end{tabular}

Mean \pm SEM of 3 replicates of 2 chicks each. Means with different lettered superscripts in a vertical row are statistically significant $(\mathrm{P}<0.05)$.

The addition of excess methionine resulted in a significant depression in body weight gain, feed intake and gain/feed ratio. The addition of glycine or threonine to the methionine excess diet caused only a slight increase in body weight gain, though the increase of body weight gain due to supplemental glycine was statistically significant. The supplemental glycine or threonine partially recovered the depressed gain/feed ratio, but these amino acids were ineffective in reversing the decreased feed intake.

Plasma methionine concentration was increased to 51 times the control value by feeding the methionine excess diet. Plasma glycine concentration was significantly decreased by feeding methionine excess diet, whereas the decrease of plasma threonine concentration was not statistically significant. The supplemental glycine and threonine to the methionine excess diet lowered plasma methionine concetration by $48 \%$ and $55 \%$, respectively, with the marked elevation of glycine and threonine supplemented in excess. 


\section{Discussion}

The beneficial effect of glycine and threonine on the growth retardation due to excess methionine was reported with chicks by KATZ and BAKER ${ }^{6}$. In the present experiment, the supplement of glycine or threonine to the methionine excess diet resulted in a slight response in body weight gain. This result seemed to be attributed to the length of the experiment, since BEnEvenga and HARPER ${ }^{3,4)}$ reported that the beneficial effect of supplemental glycine was observed after animals had been eating the diet for several days, though no information was available on threonine.

The marked increase of plasma methionine and decrease of glycine concentrations were characterized as a sign of methionine toxicity ${ }^{4,5)}$. The present experiment showed that the addition of glycine inversely reduced the plasma methionine concentration as reported by BENEVENGA and $\mathrm{HARPER}^{4)}$ and that supplemental threonine also reduced the plasma methionine concentration. In contrast to the suggestion of BENEvenga and HARPER $^{4}$, however, the lowered plasma methionine concentration due to the supplemental glycine or threonine did not increase the feed intake. This result might be attributed to the abnormality of plasma amino acid pattern resulting from compensatory elevation of plasma glycine or threonine instead of the decrease of plasma methionine.

DANIEL and WAISMAN ${ }^{2)}$ reported that the depression in feed intake due to excess amino acid was frequently associated with a marked elevation in plasma of amino acid excessively supplemented. The adverse effect of chicks caused by excess DL-methionine ${ }^{5)}$, L-lysine $\mathrm{e}^{(0)}, \mathrm{L}$-serine $\mathrm{e}^{11)}$ or $\mathrm{D}$-aspartic acid $^{12)}$ was also associated with the elevated blood concentrations of these amino acids, whereas other experiments showed that amino acid supplements, such as L-lysine, L-valine and $\mathrm{L}$-arginine ${ }^{13)}$, or $\mathrm{L}$-histidine $\mathrm{e}^{14)}$, above the requirement resulted in a marked elevation of the amino acid in plasma without any ill-effects. Thus, it is very difficult to interpret the relationship between plasma amino acid concentrations and feed intake, even though a high concentration of blood amino acid could account for some of the adverse effects.

UEDA et al..$^{9)}$ showed that the addition of $1.5 \%$ excess methionine to the $10 \%$ protein diet decreased dietary energy and nitrogen utilization as well as growth and feed intake. The result of the present experiment suggested that the beneficial effect of glycine or threonine was attributed to the improvement of dietary energy and nitrogen utilization rather than to the increase of feed intake as reflected on the increase of gain/feed ratio.

\section{Literature}

1) Harper, A.E., N.J. Benevenga and R.M. Wohlhueter: Physiol. Rev., 50, 428, 1970.

2) Daniel, R.G. and H.A. Waisman: Growth, 32, 255, 1968.

3) Benevenga, N.J. and A.E. Harper: J. Nutr., 93, 44, 1967.

4) Benebenga, N.J. and A.E. Harper: J. Nutr., 100, 1205, 1970.

5) Ueda, H., and I. Tasaki: Japan. Poultry Sci., 14, 138, 1977.

6) KatZ, R.S. and D.H. BaKeR: J. Nutr., 105, 1168, 1975.

7) Nesheim, M.C., J.D. Garlich and P.H. Hopkins: J. Nutr., 78, 89, 1962.

8) Velu, J.D., D.H. Baker and H.M. Scott: J. Nutr., 101, 1249, 1971.

9) Ueda, H., H. Yокота and I. Tasaki: Proc. XVI World's Poultry Congress, Rio de Janeiro, 
Brasil, 1649, 1978.

10) D'Mello, J.P.F. and D. Lewis: Br. Poult. Sci., 12, 345, 1971.

11) Shen, T.F., H.R. Bird and M.L. Sunde: Poultry Sci., 52, 1168, 1973.

12) Maruyama, K., M.L. Sunde and A.E. Harper: J. Nutr., 102, 1441, 1972.

13) Zimmerman, R.A. and H.M. Scott: J. Nutr., 87, 13, 1965.

14) Robbins, K.R., D.H. Baker and H.W. Norton: J. Nutr., 107, 2055, 1977.

\title{
メチオニン過剩飼料によるヒナの血漿メチオニン濃度の増加と 飼料摂取量の減少に及ぼすグリシンまたはスレオニンの影響
}

\author{
上田博史・横田浩臣・田先威和夫
}

名古屋大学農学部, 名古屋市 464

メチオニン過剩による成長阻害は飼料提取量の減少を 伴うが，食欲の調節機構は不明である。グリシンとスレ オニンは特異的にメチオニン過剩による成長阻害を緩和 する効果をもつ。またメチオニン過剩により増加した血 中メチオニン濃度はグリシン添加によって低下すること が知られており，この血中メチオニン濃度の低下が飼料 掑取量を増加させることが示唆されている。しかしスレ オニンの影響については知られていない。本実験ではメ チオニン過剩により血中に蓄積したメチオニンおよび減 少した飼料掑取量に及ぼすグリシンまたはスレオニンの 影響を調べた。

メチオニン過㮃飼料は, 抽出大豆蛋白質に適量の Lメチオニンとグリシンを補足した粗蛋白質含量 $10 \%$ の対 照飼料に， $1.5 \%$ Lーメチオニンを添加して調製した。
さらに等モルのグリシン $(0.75 \%)$ または L-スレオニ ン $(1.19 \%)$ をメチオニン過剩飼料に添加した。 8 日齢 の白レグ雄ビナをこれらの飼料で 5 日間飼育した後, 心 臓呀刺により血液を採取し，血漿のメチオニン，グリシ ンおよびスレオニン濃度を測定した。

メチオニン過剩飼料の捸取によりヒナの増体重, 飼料 䝮取量および飼料効率は著しく減少し, 血漿メチオニン 濃度は対照の 51 倍に増加した。メチオニン過剩飼料にグ リシンまたはスレオニンを添加することによって，血中 で增加したメチオニン濃度は約 $1 / 2$ に減少したが, 飼料 掑取量は增加しなかった。しかし飼料効率はこれらのア ミノ酸の添加で有意に改善された。

(家禽会誌, 16, 76〜79, 1979) 